\title{
MODELING FOR THE ANALYSIS OF THE INVESTMENT POTENTIAL OF THE CONSTRUCTION SECTOR
}

\author{
Natalya SHLAFMAN, Kateryna FROLINA, Lovorka GOTAL DMITROVIC
}

\begin{abstract}
The purpose of the article is to develop a methodology for determining the need for the amount of investment resources needed to build the investment potential (IP) of the construction sector. The methodology is found in economic and mathematical modelling. We developed a model for the analysis of the investment potential of the construction sector (IPCS) by selecting the three-factor Cobb-Douglas production function for the IPCS study and by constructing a functional dependence from the collected statistical information, which allowed us to analyse the effect of changing the value of one of the selected factors on the resulting factor. The paper shows that market participants can use the proposed methodology to determine the factors that influence the improvement of IPCS, the degree of their influence and the determination of the values necessary to achieve a given level of investment potential.
\end{abstract}

Keywords: construction sector; investment potential; mathematical modelling; method of determining the need; three-factor production function

\section{INTRODUCTION}

In modern conditions, one of the sectors with the most demand by the society and the state in its social orientation and investment capacity is the construction sector. However, as it is the case with the entire Ukraine today, the construction sector is going through a difficult period marred by an unstable economic situation, innovations in the legislative framework and an undeveloped mechanism of work under the new rules, the energy crisis and the unwillingness to accept massive transition of enterprises to energy-saving technologies. The role of the investment policy in acquiring capital investments to increase the volume of construction work and to increase the investment potential of the construction sector in the Ukraine and its regions is more regressive than progressive. An important role in ensuring the growth of the socio-economic system through its stabilization and adaptation to the changing external and internal conditions is played by the system of state regulation. At the present stage of development, the construction sector increased multiple synergistic effects of the components preceding the rational process of the organization and management of construction. In fact, no significant investment and construction project is implemented today without the collaborative component at the level of management, resource and information interactions, design and construction processes and their documentary, regulatory and technical support.

The weak investment activity of the state, enterprises and the population, high intra-industry competition and the monopoly position of some construction companies, unnecessary administrative barriers, as well as imperfections in technical regulations, the imbalance of construction norms and regulations with the international standards negatively affect business activity in the construction industry. Thus, there is an objective need to intensify investment activity and to improve the methods of regulating investment processes and their compliance with the modern needs. Scientists pay enough attention to the definition of the concept of "investment" and the categories that create the conceptual apparatus of this direction of the economic science.

The theoretical aspects of investment and the issues of state regulation of the investment activity have been developed in the writings of authors such as: J. M. Keynes, [13], V. M. Lisyuk, [16], W. Sharpe, [25], A. Harrison, I. Love and M. S. Mc Millan, [11], E. J. Dolan and E. D. Lindsay, [5] and P. Masse [17]. In modern research, which marked a further development of the theory, the methodology and practice of investment in various economic activities include the following works: European Investment Bank [6], S. Gogiashvili [9], I. So and A. Staskevicius [26], O. I. Layko [15], D. Van Horn and D. Vahovich [28], L. J. Gitman [8], I. A. Blank [1], A. F. Hoiko [12] and O. D. Danilov, H. M. Ivashyna and O. H. Chumachenko [4].

However, despite a rather deep processing of many theoretical and methodological issues and practical research on the mechanisms of the state regulation of investment in different sectors of the economic activity, including the construction industry in the state, many questions remained outside of the scope of the research. Additionally, the current economic crisis requires new approaches in the solving of the problem of the intensifying investment activity.

Thus, the purpose of the article is to develop a methodology for determining the need for the volume of investment resources necessary to form the investment potential of the construction industry on the example of the Ukraine.

\section{METHODOLOGY}

The investment potential has the capacity to stabilize the construction industry at the macro and micro levels and increase the business activity. The research of investment problems is in the sight of many domestic and foreign scholars, but it should be noted that there is a significant difference in the interpretation of key concepts in the economic scientific literature and regulatory documents, and there is still no universal definition of them that would satisfy 
the needs of both theory and practice. A basic and rather controversial concept in the investment paradigm of the construction sector is the concept of "investment", as there are many versions of it.

The term "investment" comes from the Latin word "invest" - to invest. R. Campbell, S. L. Brue and S. M. Flynn characterize investment as "the cost of production and accumulation of means of production and increase of material stocks" [2]. W. F. Sharp, G. J. Aleksander and J. V. Beyli believe that the term "investment" should mean a categorical abandonment of the present good for a (possible) value in the future [24]. L. J. Gitman has a less categorical idea when it comes to investing. His investment is seen as a way to save capital for the future by placing the initial capital in various forms [8].

Some scientists, such as J. S. Merkulov [19], S. V. Mocherny [20], A. M. Moroz [21], O. F. Pokropivny [23], D. M. Chervanov [3], whose scientific interests are mainly related to investments, treat investments as long-term investments. They argue that only through long-term capital investment can business income be achieved. It is possible that such views have arisen due to the influence of the scientific and official thought from the time of transition to a market economy, when the category of "investment" at the official level was not fully justified and considered, but what was considered was the concept of "capital investment", exclusively as an expense for the creation of new fixed assets, their expansion, reconstruction and renovation, which "were implemented in the form of long-term capital investments in various sectors of the economy" [14]. Investments are a category of financial markets that can exist and occur only in the process of distributing the inter-object redistribution of funds.

Such approaches, in our opinion, reject the possibility of short-term investments (up to one year). The current practice of investing in projects with a short-term return on capital in the face of prolonged inflationary processes and high investment risks that are characteristic of the Ukraine is entirely appropriate. Additionally, it is not necessary to identify "investments" with "capital investments", because capital investment is one of the forms of investment which is considered in the context of this study as a means for housing construction. Investments are the same as current assets, intangible assets (patents, licenses), financial instruments, etc.

In foreign economic literature, the term "investment" is emphasized as an important feature in terms of the ability of the investment process to generate revenue. Thus, the French economist $P$. Masse argues that the act of capital investment is an act of exchange to meet the today's need for the expectations of satisfying it in the future with the help of the invested goods [17]. E. J. Dolan and D. Lindsey define investment as "an increase in the amount of capital that functions in the economic system, that is, an increase in the supply of productive resources" [5].

According to the definition given by I. A. Blank, "Investment company - investing capital in all its forms in various objects (tools) i.e. business for profit and to achieve economic or non-economic effects, the implementation of which is based on market principles and due to the time factor, risk and liquidity" [1].

Therefore, most authors identify the purpose of the investment process, but do not specify the objects of investment and do not determine the nature of investment (financial, material or intellectual). In general, the emphasis on the anticipation of an increase in future capital is predominant in determining investment.

In our opinion, in today's business environment, for the realization of its economic goals, it is not enough to focus solely on profit. Long-term development involves a move towards social responsibility, which not only creates a positive image of the company, but also reduces operational risks, expands the market and increases the investment rating. Investing can cause not only economic benefits, but also an environmental and social impact.

In the writings of Western economists, investment is studied as a unity of two aspects: resources (capital values) and investments (expenses). The most complete approach is presented in the writings of the Nobel Prize laureate J. M. Keynes. He understood investment as "... the current increase in the value of capital assets as a result of the production activity of this period." This is - "... the part of the profit for a certain period that was not used for consumption." [13] However, if funds are not in circulation, it simultaneously reduces their value as a result of inflation, and on a global scale the turnover is reduced, which thus contributes to the crisis. We believe that investing is a process of attracting accumulated capital into circulation in order to generate income or benefit.

Additionally, it is believed that investment is only an investment of money, which is hard to agree with, since such operations can be carried out not only in monetary terms but also in other forms - various instruments of the stock market, intangible assets, real estate, technologies, etc. However, unused funds cannot always be attributed to investment since money, which is lagging behind and is not in circulation, cannot bring a positive value of profit and lose its value under the influence of certain factors, among which inflation is the most widespread. Therefore, we consider the appropriated interpretation of investments as a direct process of transformation into the cost of accumulated capital to obtain a certain useful effect or income.

In view of the above-mentioned investments, they should be characterized as investments (financial, material, intellectual), i.e. costs that will after some time lead to the multiplication of wealth; but income is not considered as a motive of investment activity. Investments are the essence of the time derivative of savings - what accumulates today will bring revenue tomorrow, however, the opposite will also be true - what brings profit today will in the future enable the creation of capital.

Thus, the difference between the two categories is rather conditional, but it will still allow the concept of investments in the formation of capital to be equated with the fact that it generates income on the invested capital at a given time. The motives for investing and saving various recipients are determined by the sum of factors: economic (inflation, tax policy, monetary policy), political (legislative measures, 
legal basis of investment, stability of state regulation in general), scientific and technical (level of development of technology, industrial potential), socio-economic, etc.; and also the factors of the micro-environment: availability of investment instruments, level of investment competition in the investment market, resource sufficiency, etc.

Based on the results of the analysis of definitions, we see investments as a target, a timely investment of financial, material and intellectual resources in the development of business or other business entity in order to obtain an economic, social or other effect.

Our judgments about the essence of investment activity for the construction industry are based on the disclosure of this category as targeted actions aimed at finding, evaluating and selecting potential investment objects, as well as entering into agreements relating to their acquisition or financing and ensuring a return on investment from the purpose of forming a safe and comfortable living environment, providing effective financial, economic and technical indicators of the activity of construction enterprises.

In general, the investment system of the construction industry is defined as a complex of interconnected elements of the regulatory legal form, formal and informal norms and rules of organization of the work of subjects and objects of the investment process in the implementation of their investments and in the organization of the production process (reproduction of capital) [15].

For the study of state regulation of the construction industry, it is important to define the definition of "investment potential". According to V. M. Grinyova et al. investment potential is "...an opportunity to invest for furthering its growth or investment opportunities to conduct, support or preserve anything" [10].

Under investment potential, V. I. Zubkova et al., perceive "... a set of financial and investment resources of the enterprise, allowing them to carry out an effective investment activity aimed at ensuring its efficient and sustainable business activities" [29].

K. P. Pokatayeva defines the investment potential of the enterprise as an organized set of available economic resources [22]. The investment potential of the country accumulates the investment potentials of all regions, industries and businesses. Between the potentials of different levels as sets is the relation of attachment and intersection. When determining the investment potential at all levels of the economic activity, its main macroeconomic, sociodemographic and other characteristics are taken into account, and it is generalized and acts as a weighted sum of partial potentials.

Capital investment in the construction sector contributes to the solving of the most important issue - providing housing for the population. In general, this issue should be considered not only from the point of view of solving social problems in the state, but also from the point of view of expanding the market of production of many enterprises which are affiliated with the construction industry - the production of building materials, furniture, glass, window constructions, home appliances, sets of products for the needs of housing and communal services, etc. Namely, the construction industry prompts cooperation and promotes the development of related industries.

The construction sector, especially its housing sector, is also able to function during the times of economic crisis, as the demand for housing, along with the involvement in the construction of funds is always there. The construction of housing promotes the development of regions, increases employment, contributes to the fight against unemployment and increases the welfare of the population. In the Ukraine, as well as in other developed countries, capital investments are largely filled with money from the population, and foreign investments may be desirable to focus on the formation of large and accessible-to-all segments of the population rental housing market. For the Ukrainian partners of Western investment companies, the rental property market is a guarantee of spare and relatively stable assets for the investment in construction. Additionally, the construction of rental housing positively affects the behaviour of the society, its economic development, and it stimulates the development of other industries.

The investment potential of the Ukrainian construction sector is today mainly localized in the area of residential buildings, as there is a demand for these objects among the population; while industrial, social and communal construction work is practically not conducted due to lack of investment. During a crisis of the Ukrainian economy, investors, both foreign and domestic, will not risk investing their financial resources in the construction and the creation of production facilities, as there is no guarantee of their use and payback.

Today, scientists and experts agree that in the near future, until the economic situation in the country does not stabilize, one should not expect the arrival of investments in the construction industry. The construction of social facilities (kindergartens, hospitals, schools) and the communal infrastructure is entirely dependent on the filling of local budgets and the desire of the local authorities to create and repair these objects, as well as on the state of the development of partnership in investment activities between the local authorities and entrepreneurship in the construction industry.

Currently, foreign investment in the construction sector in the Ukraine is insignificant ( $3 \%$ in 2015). A foreign investor is best placed to invest in the Ukrainian real estate, because prices in the Ukraine are still lower than in Europe, and the authorities emit a good attitude and are willing to cooperate with foreign businessmen investing in the Ukrainian economy. The actions of investors in this direction will stimulate the employment of the population of cities and regions, they will also promote decentralization processes because they will fill local budgets with taxes and, most importantly, they will contribute to the growth of the investment potential of the construction sector as a whole.

Consequently, it is necessary to analyse and evaluate the investment potential of the construction industry, especially the industrial construction sector and the construction of infrastructure objects, such as industrial, transport, and social objects. 


\section{THE MODEL}

In order to assess the investment potential, it is necessary to substantiate the indicators used to determine the process of capital investment and its developments in the industry, and changes in the volume of construction work that was observed not only in the past, but also needs to be observed in terms of future opportunities. To construct a model for analysing the investment potential of the construction industry in order to make a rational decision, we will initially conduct studies in which we will define a system of formalized factors that will allow the local governments to choose the best of the proposed alternatives in terms of regional significance, strategic feasibility and investment effectiveness of the impact on the investment potential of the construction industry. Determining the need for the total amount of investment resources necessary for the formation of investment potential is an important part of the state regulation of investment activity of construction organizations and it is being developed in a phased manner.

\subsection{Selection of Formalized Factors, Essential in Terms of Building the Investment Potential of the Construction Industry}

Theoretically, the number of factors for constructing a model of an analysis that could be selected to determine the investment potential of the construction sector is quite significant, because its investment potential is shaped by the following factors: natural, socio-labour, innovation, economic, institutional, infrastructural, financial and consumer resources, etc. However, the application of a number of provisions of the theory of systems, namely the principles of the necessary variety of system elements, the minimum sufficiency and the target orientation of these elements allow you to limit their number.

The choice of formal factors significant in terms of increasing the investment potential of the construction industry will be based on the availability and accessibility of statistical information.

According to research of the National Institute for Strategic Studies under the President of the Ukraine, the level of the investment (use) of capital investments is highlighted by the level of investment attractiveness of the industry, and among the main factors influencing the formation of the investors' preferences and the formation of the investment potential of the industry are the attraction of foreign direct investment and the state of fixed assets.

In modelling the investment potential of the construction industry as the initial characteristics of the model, we will consider the growth rate of capital investments (the ratio of the investment volume for the current year to the volume of investments in the previous period).

The main determinants of the impact on the investment potential of the construction industry are as follows:

- the growth rate of foreign direct investment (equity) (calculated as the ratio of annual FDI inflows to the sector in the current year to the amount of the previous year),
- the growth rate of construction (the indicator of the dynamics of construction, calculated as the ratio of the volume of construction work performed in the current year to the volume of construction work in the previous year (the index of the volume of construction works)),

- the growth factor of fixed assets of the industry (ratio of the amount of fixed assets at the end of the year to their value at the beginning of the year).

\subsection{Selecting a Mathematical Model and Collecting the Necessary Information}

Research of the investment potential of the construction industry is carried out with the help of a three-factor production function $Y=F\left(X_{1}, X_{2}, X_{3}\right)$.

Calculations of the components in the assessment of the investment attractiveness of the construction industry are based on the information of the State Statistics Service of the Ukraine and are shown in Table1.

It should be noted that in 2014, foreign direct investment in the Ukraine decreased significantly due to a sharp drop in hryvnia and the outflow of equity.

Table 1 Indicators for the analysis of the investment potential of the construction industry [27]

\begin{tabular}{|c|c|c|c|c|}
\hline & \multicolumn{4}{|c|}{ Indexes } \\
\cline { 2 - 5 } Year & $\begin{array}{c}\text { The growth } \\
\text { rate of capital } \\
\text { investment } \\
\text { The growth } \\
\text { rate of foreign } \\
\text { direct } \\
\text { investment } \\
\text { (equity) }\end{array}$ & $\begin{array}{c}\text { The growth } \\
\text { The growth rate } \\
\text { of construction } \\
\text { fixed assets } \\
\text { of the } \\
\text { industry }\end{array}$ \\
\hline 2001 & $Y_{i}$ & $X_{1 i}$ & $X_{2 i}$ & $X_{3 i}$ \\
\hline 2002 & 1.40 & 1.30 & 0.90 & 1.01 \\
\hline 2003 & 1.64 & 1.40 & 0.84 & 1.02 \\
\hline 2004 & 1.88 & 1.44 & 1.15 & 1.08 \\
\hline 2005 & 1.09 & 1.73 & 1.10 & 1.04 \\
\hline 2006 & 1.28 & 3.48 & 0.93 & 1.10 \\
\hline 2007 & 1.47 & 0.60 & 1.09 & 1.21 \\
\hline 2008 & 1.37 & 1.68 & 1.10 & 1.28 \\
\hline 2009 & 0.49 & 0.77 & 0.85 & 1.41 \\
\hline 2010 & 0.93 & 0.70 & 0.40 & 1.10 \\
\hline 2011 & 1.72 & 1.07 & 0.79 & 1.03 \\
\hline 2012 & 0.97 & 1.16 & 1.16 & 1.17 \\
\hline 2013 & 1.08 & 0.90 & 0.92 & 1.02 \\
\hline 2014 & 0.98 & 0.001 & 0.89 & 1.17 \\
\hline & & & & 0.99 \\
\hline
\end{tabular}

\subsection{Conducting Calculations}

Construction of a three-factor production function

We are aware of the statistical data of individual components of the investment potential of the industry for the $n$ previous periods.

$Y$ - factor resulting in the investment potential of the construction industry;

$X_{1}, X_{2}, X_{3}-$ key factors of the investment potential.

Let us denote:

$Y_{i}$ - the value of the resulting factor in the i-period;

$X_{j i}$ - the value of the $\mathrm{j}$-factor in that i-period. 
(Tab. 2).

Tab. 1 will in the symbolic form have the following form

\begin{tabular}{|c|c|c|c|c|}
\hline No. & $Y$ & $X_{1}$ & $X_{2}$ & $X_{3}$ \\
\hline 1 & $Y_{1}$ & $X_{11}$ & $X_{21}$ & $X_{31}$ \\
\hline 2 & $Y_{2}$ & $X_{12}$ & $X_{22}$ & $X_{32}$ \\
\hline \multicolumn{5}{|c|}{ } \\
\hline$i$ & $Y_{i}$ & $X_{j i}$ & $X_{j i}$ & $X_{j i}$ \\
\hline \multicolumn{5}{|c|}{ 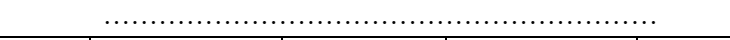 } \\
\hline$n$ & $Y_{n}$ & $X_{1 n}$ & $X_{2 n}$ & $X_{3 n}$ \\
\hline
\end{tabular}

Tab. 2 actually establishes a functional relationship between the resulting factor $Y$ and factors $X_{1}, X_{2}, X_{3}$, i.e. $Y$ is a function of three variables.

The given functional dependence is represented by a formula based on the theory of production functions, which was developed by American scholars D. Cobb and P. Douglas, who proposed one of the most well-known varieties of production functions, called the function of CobbDouglas.

General view of this feature:

$Y=A \prod_{i=1}^{n} x_{i}^{a}$

where $Y$ - resultant factor;

$A$ - numerical parameter of the production function;

$X_{i}-i^{\text {th }}$ argument, i.e., the value of the $i^{\text {th }}$ factor of the production function;

$a_{i}$-index of the degree of the $i^{\text {th }}$ argument.

In our case, we will have:

$Y=A X_{1}^{a_{1}} X_{2}^{a_{2}} X_{3}^{a_{3}}$

By performing logarithmic operations (2), we get:

$\ln Y=\ln A+a_{1} \ln X_{1}+a_{2} \ln X_{2}+a_{3} \ln X_{3}$

or after the replacement: $\ln Y=y, \ln A=a_{0}, \ln X_{1}=x_{1}, \ln X_{2}=$ $x_{2}, \ln X_{3}=x_{3}$

$y=a_{0}+a_{1} x_{1}+a_{2} x_{2}+a_{3} x_{3}$

Let us denote through $y_{i}=\ln Y_{i}, \quad x_{i j}=\ln X_{i}(i=$ $1, \ldots, n),(j=1,2,3)$ - the value of the new variables in the $i^{\text {th }}$ period.

Eq. (4) for the $t^{\text {th }}$ period takes the form:

$y=a_{0}+a_{1} x_{1 i}+a_{2} x_{2 i}+a_{3} x_{3 i}(i=1, \ldots, n)$

In fact, (5) is a system of linear algebraic equations. Such a system for $n>4$, according to the Kronecker-Capelli theorem, has no precise solution, so we will try to (5) execute approximately, but with the slightest error.

$y_{i} \approx a_{0}+a_{1} x_{1 i}+a_{2} x_{2 i}+a_{3} x_{3 i}$
Apply to (6) the method of least squares. To do this, we write the target function:

$S=\sum_{i=1}^{n}\left[y_{i}-a_{0}-a_{1} x_{1 i}-a_{2} x_{2 i}-a_{3} x_{3 i}\right] \rightarrow \min$

where $S=S\left(a_{0}, a_{1}, a_{2}, a_{3}\right)$.

According to Fermat's theorem for finding the extremum of the function $S$, we find its partial derivatives and equate to zero:

$\left\{\begin{array}{l}\frac{d S}{d a_{0}}=-2 \sum_{i=1}^{n}\left[y_{i}-a_{0}-a_{1} x_{1 i}-a_{2} x_{2 i}-a_{3} x_{3 i}\right]=0 \\ \frac{d S}{d a_{1}}=-2 \sum_{i=1}^{n}\left[y_{i}-a_{0}-a_{1} x_{1 i}-a_{2} x_{2 i}-a_{3} x_{3 i}\right] x_{1 i}=0 \\ \frac{d S}{d a_{2}}=-2 \sum_{i=1}^{n}\left[y_{i}-a_{0}-a_{1} x_{1 i}-a_{2} x_{2 i}-a_{3} x_{3 i}\right] x_{2 i}=0 \\ \frac{d S}{d a_{3}}=-2 \sum_{i=1}^{n}\left[y_{i}-a_{0}-a_{1} x_{1 i}-a_{2} x_{2 i}-a_{3} x_{3 i}\right] x_{3 i}=0\end{array}\right.$

After the transformations, we will have:

$a_{0} n+a_{1} \sum_{i=1}^{n} x_{1 i}+a_{2} \sum_{i=1}^{n} x_{2 i}+a_{3} \sum_{i=1}^{n} x_{3 i}=\sum_{i=1}^{n} y_{i}$

$a_{0} \sum_{i=1}^{n} x_{1 i}+a_{1} \sum_{i=1}^{n} x_{1 i}^{2}+a_{2} \sum_{i=1}^{n} x_{1 i} x_{2 i}+$

$+a_{3} \sum_{i=1}^{n} x_{1 i} x_{3 i}=\sum_{i=1}^{n} y_{1 i} y_{i}$

$a_{0} \sum_{i=1}^{n} x_{2 i}+a_{1} \sum_{i=1}^{n} x_{1 i} x_{2 i}+a_{2} \sum_{i=1}^{n} x_{2 i}^{2}+$

$+a_{3} \sum_{i=1}^{n} x_{2 i} x_{3 i}=\sum_{i=1}^{n} y_{i} y_{2 i}$

$a_{0} \sum_{i=1}^{n} x_{3 i}+a_{1} \sum_{i=1}^{n} x_{1 i} x_{3 i}+a_{2} \sum_{i=1}^{n} x_{2 i} x_{3 i}+$ $+a_{3} \sum_{i=1}^{n} x_{3 i}^{2}=\sum_{i=1}^{n} y_{i} y_{3 i}$

or in the matrix form $(\boldsymbol{B})$ :

$\left(\begin{array}{cc}n & \sum_{i=1}^{n} \\ \sum_{i=1}^{n} x_{1 i} & \sum_{i=1}^{n} \\ \sum_{i=1}^{n} x_{2 i} & \sum_{i=1}^{n} \\ \sum_{i=1}^{n} x_{3 i} & \sum_{i=1}^{n}\end{array}\right.$
$=\left(\begin{array}{c}\sum_{i=1}^{n} y_{i} \\ \sum_{i=1}^{n} y_{i} x_{1 i} \\ \sum_{i=1}^{n} y_{i} x_{2 i} \\ \sum_{i=1}^{n} y_{i} x_{3 i}\end{array}\right)$

$\left.\begin{array}{cc}\sum_{i=1}^{n} x_{2 i} & \sum_{i=1}^{n} x_{3 i} \\ \sum_{i=1}^{n} x_{1 i} x_{2 i} & \sum_{i=1}^{n} x_{1 i} x_{3 i} \\ \sum_{i=1}^{n} x_{2 i}^{2} & \sum_{i=1}^{n} x_{2 i} x_{3 i} \\ \sum_{i=1}^{n} x_{2 i} x_{3 i} & \sum_{i=1}^{n} x_{3 i}^{2}\end{array}\right)\left(\begin{array}{l}a_{0} \\ a_{1} \\ a_{2} \\ a_{3}\end{array}\right)=$

By the method of the inverse matrix (10), we find the components of the desired vector $a_{0}, a_{1}, a_{2}, a_{3}$. From here: $A=e^{a_{0}}$.

Numerical calculations

We are building the matrix $\boldsymbol{B}$ :

$\boldsymbol{B}=\left(\begin{array}{cccc}n & \sum_{i=1}^{n} x_{1 i} & \sum_{i=1}^{n} x_{2 i} & \sum_{i=1}^{n} x_{3 i} \\ \sum_{i=1}^{n} x_{1 i} & \sum_{i=1}^{n} x_{1 i}^{2} & \sum_{i=1}^{n} x_{1 i} x_{2 i} & \sum_{i=1}^{n} x_{1 i} x_{3 i} \\ \sum_{i=1}^{n} x_{2 i} & \sum_{i=1}^{n} x_{1 i} x_{2 i} & \sum_{i=1}^{n} x_{2 i}^{2} & \sum_{i=1}^{n} x_{2 i} x_{3 i} \\ \sum_{i=1}^{n} x_{3 i} & \sum_{i=1}^{n} x_{1 i} x_{3 i} & \sum_{i=1}^{n} x_{2 i} x_{3 i} & \sum_{i=1}^{n} x_{3 i}^{2}\end{array}\right)=$ 
$=\left(\begin{array}{cccc}14 & -5.1978 & -1.5502 & 1.4694 \\ -5.1978 & 50.9610 & 2.0984 & 0.0758 \\ -1.5502 & 2.0984 & 1.1178 & -0.1021 \\ 1.4694 & 0.0758 & -0.1021 & 0.2912\end{array}\right)$

$b=\left(\begin{array}{l}a_{0} \\ a_{1} \\ a_{2} \\ a_{3}\end{array}\right)=\left(\begin{array}{l}2.5946 \\ 1.2697 \\ 0.7329 \\ 0.3452\end{array}\right)$

The inverse matrix $\hat{A}^{-1}$ will look as:

$$
\boldsymbol{B}^{-1}=\left(\begin{array}{cccc}
0.1877 & 0.0142 & 0.1517 & -0.8977 \\
0.0142 & 0.0225 & -0.0305 & -0.0884 \\
0.1517 & -0.0305 & 1.1292 & -0.3616 \\
-0.8977 & -0.0884 & -0.3616 & 7.8592
\end{array}\right)
$$

Then

$$
\left(\begin{array}{l}
a_{0} \\
a_{1} \\
a_{2} \\
a_{3}
\end{array}\right)=\boldsymbol{B}^{-1} b=\left(\begin{array}{l}
0.3064 \\
0.0126 \\
1.0576 \\
0.0067
\end{array}\right)
$$

From here: $A=e^{a_{0}}=\mathrm{e}^{0.3064}=1.3585$

Thus, Eq. (2) will have the following form:

$$
Y=1.3585 X_{1}^{0.0126} X_{2}^{1.0576} X_{3}^{0.0067}
$$

\subsection{Drawing Conclusions}

The obtained functional dependence allows us to carry out an analysis of the effect of changing the value of one of the selected factors $\left(X_{1}, X_{2}, X_{3}\right)$ on the resulting factor $Y$. Thus, according to the results of the research of the National Institute for Strategic Studies under the President of the Ukraine, the main factors shaping the investment potential of the industry are "the rate of growth of foreign direct investment (equity)" $\left(X_{1}\right)$ which affects a little, but the influence of the factor of "the coefficient of growth of the fixed assets of the industry" $\left(X_{3}\right)$ is almost absent. The factor of "the growth rate of construction" $\left(X_{2}\right)$ affects significantly the resulting factor of "the rate of growth of capital investment".

Given that the average factor of the "growth factor of the fixed assets of the industry" $\left(X_{3}\right)$ is 1.12 (from the Tab. 1), $1.12^{0,0067}=1.0008 \approx 1$ and the impact on the performance indicator is small, functional dependence can then be expressed:

$Y=1.3585 X_{1}^{0.0126} X_{2}^{1.0576}$

Graphic interpretation of the obtained Eq. (14) gives a visual representation of the nature of the factors' dependence: "the rate of growth of capital investment" $(Y)$, "the growth rate of foreign direct investment (equity)" $\left(X_{1}\right)$ and "the growth rate of construction" $\left(X_{2}\right)$ as shown in Fig. 1.

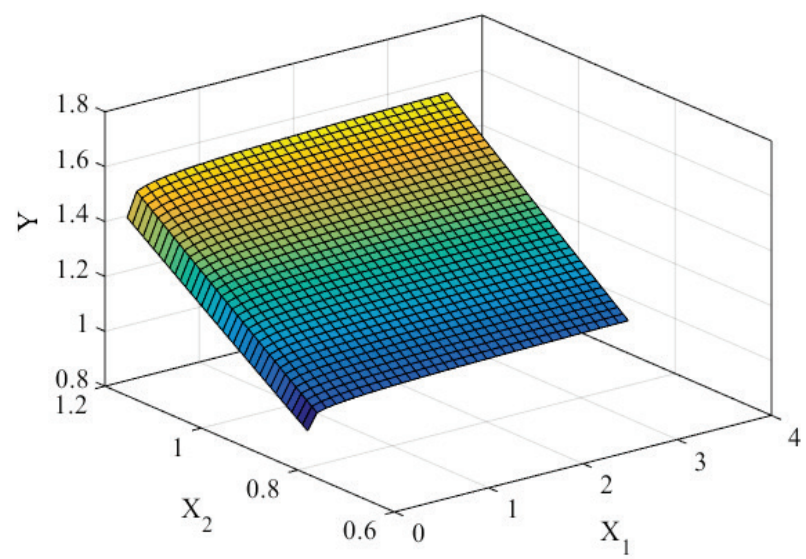

Figure 1 Graphic interpretation of functional dependence

The average value $X_{1}^{0.0126}\left(1.2^{0.0126}\right)$ equals $1.0023 \approx 1$, and as a result we get the following functional dependence of the resulting factor on the "growth rate of construction", which significantly affects it:

$Y=1.3585 X_{2}^{1.0576}$

The graph of function (15) will be a straight line passing through the origin.

Thus, the factors $X_{1}, X_{3}$ do not have a significant impact on the resultant indicator of "the rate of growth of capital investment", and in subsequent studies and calculations, they cannot be taken into account.

Factor $X_{2}-$ The "growth rate of construction" significantly affects the "growth rate of capital investment", which characterizes the investment potential of the industry, and the functional dependence has the form (15) (with an increase of $X_{2}$ by $1, Y$ will increase by 1.3585 times).

Thus, the sensitivity of the volume of construction products to the integral indicator of capital investment in the construction sector is growing to a large extent. Therefore, the decision to increase the volume of construction products is effective in changing the approaches towards increasing the investment potential and hence towards the formation of an investment policy.

We shall now consider the properties of the characteristics of the function (13).

1. Factors' elasticity. These figures show by how many percent will $Y$ change if $X_{\mathrm{i}}$ is increased by $1 \%$, leaving other factors unchanged.

For the $1^{\text {st }}$ factor we get

$E_{x 1}=\frac{x_{1} \frac{a Y}{a x_{1}}}{Y}=\frac{x_{1} A a_{1} X_{1}^{a_{1}-1} X_{2}^{a_{2}} X_{3}^{a_{3}}}{Y}=\frac{a_{1} A X_{1}^{a_{1}} X_{2}^{a_{2}} X_{3}^{a_{3}}}{Y}=\frac{a_{1} Y}{Y}=a_{1}$

where $E_{x_{1}}$ - elasticity of the $1^{\text {st }}$ factor.

Thus, for the $i^{\text {th }}$ factor, we obtain

$E_{x j}=a_{j}$ 
If $X_{2}$ - the growth rate of construction increases by $1 \%$, leaving other factors unchanged, then $Y-$ the growth rate of capital investment will increase by $1.0576 \%$. Similarly, with an increase of $1 \%$ for $X_{1}$ - the growth rate of direct foreign investment (equity) or $\mathrm{X}_{3}$ - the growth factor of the fixed assets of the industry, $\mathrm{Y}$ will increase - the growth rate of capital investments by $0.0126 \%$ and $0.0067 \%$, respectively.

2. Limiting factor productivity. With an increase of the $i^{\text {th }}$ factor per unit, the resultant factor will increase by a magnitude of $\frac{\partial Y}{\partial X_{i}}$. In practice, when planning incomes and expenditures, it is often erroneously believed that the magnitude of the increase is $\frac{Y}{X_{i}}$.

Therefore, for the $1^{\text {st }}$ factor we get a similar result as for the $2^{\text {nd }}$ and $3^{\text {rd }}$ factors.

$\frac{\partial Y}{\partial X}=a_{1} A X_{1}^{a_{1}-1} X_{2}^{a_{2}} X_{3}^{a_{3}}$

$\frac{Y}{X_{1}}=A X_{1}^{a_{1}-1} X_{2}^{a_{2}} X_{3}^{a_{3}}$

$\frac{\partial Y}{\partial X_{1}}=a_{1} \frac{Y}{X_{1}}$ that is to say $\frac{\partial Y}{\partial X_{1}} \leq \frac{Y}{X_{1}}$

3. Determining the values of the factors necessary to achieve a given resultant factor. Find the minimum values of the factors $X_{1}, X_{2}, \mathrm{X}_{3}$, required to achieve a given $Y$. To do this, we have the following problem of nonlinear programming:

$\left\{\begin{array}{c}I=X_{1}+X_{2}+X_{3} \rightarrow \min \\ A X_{1}^{a_{1}} X_{2}^{a_{2}} X_{3}^{a_{3}}=Y \\ X_{1} ; X_{2} ; X_{3} \geq 0\end{array}\right.$

To solve it, we apply the Lagrange multiplier method.

$L\left(X_{1} ; X_{2} ; X_{3}\right)=$

$=X_{1}+X_{2}+X_{3}+\lambda\left[Y-A X_{1}^{a_{1}} X_{2}^{a_{2}} X_{3}^{a_{3}}\right] \rightarrow \max$

$\left\{\begin{array}{c}\frac{d L}{d X_{1}}=1-\lambda\left(a_{1} A X_{1}^{a_{1}-1} X_{2}^{a_{2}} X_{3}^{a_{3}}\right)=0 \\ \frac{d L}{d X_{2}}=1-\lambda\left(a_{2} A X_{1}^{a_{1}} X_{2}^{a_{2}-1} X_{3}^{a_{3}}\right)=0 \\ \frac{d L}{d X_{3}}=1-\lambda\left(a_{3} A X_{1}^{a_{1}} X_{2}^{a_{2}} X_{3}^{a_{3}-1}\right)=0 \\ \frac{d L}{d X_{1}}=Y-A X_{1}^{a_{1}} X_{2}^{a_{2}} X_{3}^{a_{3}}=0\end{array}\right.$

Conditions of optimality

$\frac{1}{\lambda}=a_{1} A X_{1}^{a_{1}-1} X_{2}^{a_{2}} X_{3}^{a_{3}}=a_{2} A X_{1}^{a_{1}} X_{2}^{a_{2}-1} X_{3}^{a_{3}}=$

$=a_{1} A X_{1}^{a_{1}} X_{2}^{a_{2}} X_{3}^{a_{3}-1} \rightarrow \frac{a_{1}}{x_{1}}=\frac{a_{2}}{x_{2}}=\frac{a_{3}}{x_{3}}$

We will make a replacement $X$ - to a new variable $X_{i}=a_{i} X$. Then the optimality conditions will be fulfilled for any $\mathrm{X}$. We make a substitution in the fourth equation of the system (21) equality $X_{i}=a_{i} X$ and find $X$ :

$$
\begin{aligned}
& Y-A\left(a_{1} X\right)^{a_{i}}\left(a_{2} X\right)^{a_{2}}\left(a_{3} X\right)^{a_{3}}=0 \\
& A\left(a_{1} X\right)^{a_{i}}\left(a_{2} X\right)^{a_{2}}\left(a_{3} X\right)^{a_{3}}=Y \\
& A a_{1}{ }^{a_{i}} a_{2}{ }^{a_{2}} a_{3}{ }^{a_{3}} X^{a_{1} a_{2} a_{3}}=Y \\
& X^{a_{1} a_{2} a_{3}}=\frac{Y}{A a_{1} a_{i} a_{2} a_{2} a_{3} a_{3}} \\
& X=\left(\frac{Y}{A a_{1} a_{i} a_{2} a_{2} a_{3} a_{3}}\right)^{1 /\left(a_{1}+a_{2}+a_{3}\right)}
\end{aligned}
$$

Then

$$
\begin{aligned}
& X_{i}=a_{i} X=a_{i}\left(\frac{Y}{A a_{1} a_{i} a_{2} a_{2} a_{3} a_{3}}\right)^{1 /\left(a_{1}+a_{2}+a_{3}\right)} \\
& I_{\text {min }}=\left(a_{1}+a_{2}+a_{3}\right)\left(\frac{Y}{A a_{1} a_{i} a_{2} a_{2} a_{3} a_{3}}\right)^{1 /\left(a_{1}+a_{2}+a_{3}\right)}
\end{aligned}
$$

To achieve the given resultant factor $Y$, the minimum required index I (sum of factors) will be equal to $I_{\min }(24)$, thus it is possible to find the minimum necessary factors of the factors $X_{1}, X_{2}, X_{3}$.

On the whole, the preliminary assumption about the level of the expansion of investment potential has been mathematically confirmed.

\section{CONCLUSION}

The article proposes the scientific principles of determining the need for the total volume of investment resources necessary for the formation of investment potential in a four-stage structure with the use of a three-factor production function.

The conducted studies showed that the subjects of market activity, investors, can use the proposed mathematical apparatus in order to determine the factors that affect the improvement of the investment potential of the industry, the degree of their influence, thus determining the values necessary to achieve a given level of investment potential.

The results obtained in this article should be used for further substantiation of the priority directions of the state investment policy in the construction industry and in the search of effective tools for its implementation.

\section{REFERENCES}

[1] Blank, I. A. (2006). Investitsionnyiy menedzhment : uchebnyiy kurs. 2 izd. K.: Nika-Tsentr, Elga.

[2] McConnell, C. R., Brue, S. L., \& Flynn, S. M. (2013) Economics: principles, problems, and policies. $18^{\text {th }}$ ed. New York, McGraw-Hill/Irwin.

[3] Chervanov, D. M. (1999). Management of innovation and investment development of enterprises of Ukraine. Knowledge, KOU.

[4] Danilov, O. D., Ivashyna, H. M., \& Chumachenko, O. H. (2001). Investuvannia: navch. posib. K.: Vydavnychyi dim "Kompiuter-pres".

[5] Dolan, E. J. \& Lindsay, D. E. (1992). Market: microeconomic model. St. Petersburg: The Printing Yard. 
[6] European Investment Bank (2017). Wind of change: Investment in Central, Eastern and South Eastern Europe. http://www.eib.org/attachments/efs/economics_study_wind_o f_change_investment_in_cesee_en.pdf_ (Accessed: 13.05.2018)

[7] Fedoseev, V. V. et al. (2002). Ekonomiko-matematicheskie metodyi i prikladnyie modeli: ucheb. posobie dlya vuzov. M.: YuNITI.

[8] Gitman, L. J. (2010). Principles of Managerial Finance, $11^{\text {th }}$ Edition. http://www.külker.hu/wp-content/uploads/2013/03/ 30459588-Principles-of-Managerial-Finance-by-Gitman.pdf (Accessed 13.05.2018)

[9] Gogiashvili, S. (2016). Current Issues of the Formation of the Investment Environment and Potential in Georgia. Creative and Knowledge Society, De Gruyter Open, 6(1), 1-13. https://doi.org/10.1515/cks-2016-0002

[10] Grinyova, V. M., Koyda, V. O., Lepeiko, T. I., \& Koude, O. P. (2008). Investing: a textbook. Kyiv: Knowledge.

[11] Harrison, A., Love, I., \& McMillan, M. S. (2002). Global Capital Mows and Financial Constraints. NBER Working Paper, (No. 8887).

[12] Hoiko, A. F. (1999). Metody otsinky efektyvnosti investytsii ta priorytetni napriamy yikh realizatsii. K.: Vira-R.

[13] Keyns, J. M. (1997). The general theory of employment, interest, and money. Amherst, NY: Prometheus Books.

[14] Konoplitsky, V. \& Filina, A. (1996). This is a business. Glossary of Economic Terms. Kiev: AlterPres.

[15] Layko, O. I. (2014). Transformatsiyni protsesi v investitsiyniy sistemi ekonomiki Ukrayini: monografiya. Odesa: FOP GrIn D.S.

[16] Lisyuk, V. M. (2011). Vosproizvodstvennaya funktsiya tovarnyih ryinkov. Odesa: IPREED NAN Ukrayini.

[17] Masse, P. (1971). Criteria and Methods of Optimal Determination of Capital Investment. Moscow: Statistics.

[18] Mayorova, T. V. et al. (2012). Aktivizatsiya investitsionnogo protsessa $v$ Ukraine: kollektivnaya monografiya. M.: Finansyi.

[19] Merkulov, J. S. (2010). Investments: a tutorial. Moscow: INFRA-M.

[20] Mocherny, S. V. (2000). Economic Encyclopedia: 3 t. for ed. K.: Center "Academy", V. 1.

[21] Moroz, A. M. et al. (1993). Bank Encyclopedia. K.: Track.

[22] Pokatayeva, K. P. (2007). Theoretical aspects of definition of categories "investment potential" and "investment attractiveness". Kommunal'noe hojejstvo of cities: scientific and technical. Sat Series: Economic Sciences, 2007(75), 262268.

[23] Pokropivny, O. F. (1995). Economy of the enterprise: a textbook for the studio. econ universities and fac. in 2 vols. K.: Wave Press, V. 1.

[24] Sharp, W. F., Aleksander, G. J., \& Beyli, J. V. (2001). Investitsii. M.: Infra-M.

[25] Sharpe, W. (2006). Investors and Markets: Portfolio Choices, Asset Prices, and Investment Advice (Princeton Lectures in Finance). Hardcover - October 22.

[26] So, I. \& Staskevicius, A. (2015). Measuring the "impact" in impact investing. MBA Harvard Business School Faculty Supervisor: Alnoor Ebrahim. https://www.hbs.edu/ socialenterprise/Documents/MeasuringImpact.pdf

[27] State Statistics Service of Ukraine, http://www.ukrproject.gov.ua)

[28] Van Horn, D. \& Vahovich, D. (2008). Osnovyi finansovogo menedzhmenta: Per. s angl. 12-e izd. M.: Vilyams.

[29] Zubkova, V. I., Nakyaylo, A. V., \& Losev, S. A. (2001). The financial and investment potential of the enterprise and its influence on the management of investments. Culture of the peoples of the Black Sea region, (20), 34-37.

\section{Authors' contacts:}

Natalya SHLAFMAN, DrHab (Economics)

Institute for Market Problems and Economic and Environmental Studies of the National Academy of Sciences of Ukraine,

29, French Boulevard st., Odessa, 65044, Ukraine

E-mail: natashl@ukr.net

Kateryna FROLINA PhD (Economics)

Odessa State Academy of Civil Engineering and Architecture,

4 Didrihsona st., Odessa, 65029, Ukraine

E-mail: kateryna.frolina@gmail.com

Lovorka GOTAL DMITROVIC, PhD, Assistant Professor

University North,

104. brigade 3, Varazdin, Croatia

E-mail: Igotaldmitrovic@unin.hr 